\title{
MEDIA DARING LAYANAN BK DI MASA PANDEMI COVID-19
}

\author{
Ana Musdalifah \\ Universitas Surabaya \\ ana.musdalifah1982@gmail.com
}

\begin{abstract}
The Covid-19 pandemic occurred in all countries in the world, including Indonesia. The purpose of writing is to obtain information that is relevant to BK service media during the Covid-19 pandemic which is currently happening all over the world, including Indonesia. Information gathering is done through library research by collecting library collection materials, which are then presented in narrative form. BK services during the Covid-19 pandemic used various online media to facilitate indirect interactions that can be done anytime and anywhere. BK service system is implemented through technological devices connected to an internet network connection. Counselors can provide services together at the same time by using social media such as whats app (WA), telegram, instagram, zoom applications or other media.
\end{abstract}

Keywords: BK services, media services, the covid-19 pandemic

\begin{abstract}
Abstrak: Masa pandemi Covid-19 ini terjadi di semua negara di dunia termasuk Indonesia. Tujuan tulisan untuk mendapatkan informasi yang relevan dengan media layanan BK di masa pandemi Covid-19 yang saat ini terjadi di seluruh penjuru dunia termasuk Indonesia. Pengumpulan informasi dilakukan melalui studi kepustakaan dengan mengumpulkan bahanbahan koleksi perpustakaan yang kemudian hasilnya disajikan dalam bentuk narasi. Layanan BK di masa pandemi covid-19 menggunakan berbagai media daring untuk memudahkan interaksi secara tidak langsung yang dapat dilakukan kapan dan dimana saja. Sistem layanan BK dilaksanakan melalui perangkat teknologi yang terhubung dengan koneksi jaringan internet. Konselor dapat melakukan pemberian layanan bersama-sama di waktu yang sama dengan menggunakan media sosial seperti whats app (WA), telegram, instagram, aplikasi zoom ataupun media lainnya.
\end{abstract}

Kata kunci: Layanan BK, media layanan, pandemi covid-19

\section{PENDAHULUAN}

Covid-19 saat ini menjadi pandemi yang serius di seluruh penjuru dunia termasuk Indonesia. Menurut Aji (2020) mengatakan bahwa kesamaan situasi Indonesia dengan negara-negara lain di belahan dunia mesti segera diatasi dengan seksama. Seluruh kegiatan yang berbentuk kerumunan, keramaian dan interaksi secara langsung telah dilarang oleh pemerintah, tidak terkecuali kegiatan belajar mengajar. Pandemi covid-19 memaksa kebijakan social distancing untuk meminimalkan persebaran covid-19. Kementerian Pendidikan di bawah kepemimpinan Menteri Nadiem Makarim, mendengungkan semangat peningkatan produktivitas bagi peserta didik untuk mengangkat peluang kerja ketika menjadi lulusan sebuah sekolah. Namun dengan hadirnya wabah covid-19 yang sangat mendadak, maka dunia pendidikan Indonesia perlu mengikuti alur yang sekiranya dapat menolong kondisi sekolah dalam keadaan darurat. Menteri Pendidikan dan Kebudayaan 
RI Nadiem Makarim merespon dengan belajar di rumah menggunakan media daring.

Melalui metode daring peserta didik diharuskan memiliki tanggung jawab mandiri dalam belajar, dapat mengontrol sikapnya dalam belajar, menyelesaikan tugas melalui daring dan mengoptimalkan gadget sebagai sumber belajar. Namun menurut surat kabar Kompas (2020) disampaikan bahwa masih ada beberapa peserta didik yang mengalami hambatan dalam pembelajaran daring, salah satunya mengalami kebosanan tinggal di rumah. Disinilah peran bimbingan konseling sangatlah penting dalam memberikan layanan untuk membantu mengatasi permasalahan peserta didik selama pembelajaran daring di tengah pandemi covid-19. Hal ini bertujuan untuk mengetahui perkembangan kompetensi dan kemandirian peserta didik.

Dengan adanya proses pembelajaran menggunakan daring sesuai instruksi Mentri Pendidikan, maka media layanan bimbingan konseling juga harus mampu memotivasi peserta didik untuk belajar dan tetap tinggal di rumah serta mengembangkan life skill di masa pandemi secara online. Fenomena ini menjadi tantangan dan tuntutan bimbingan konseling untuk mampu menerapkan berbagai bentuk media layanan dengan mengoptimalkan aplikasi, sedangkan dari peserta didik dituntut mampu beradaptasi dengan sistem daring yang baru bagi mereka.

Media merupakan salah satu penunjang dalam proses pemberian layanan konseling di tengah pandemi covid-19. Berhasil dan tidaknya proses layanan sangat ditentukan oleh media yang digunakan. Menurut Arsyad (2005) media adalah segala sesuatu yang dapat digunakan untuk menyalurkan pesan dari pengirim ke penerima sehingga dapat merangsang pikiran, perasaan, perhatian dan minat peserta didik sedemikian rupa sehingga terjadi proses belajar. Menurut Dabbagh dan Ritland (2009) menjelaskan, pembelajaran online adalah sistem belajar yang terbuka dan tersebar dengan menggunakan perangkat pedagogi (alat bantu pendidikan), yang dimungkinkan melalui internet dan teknologi berbasis jaringan untuk memfasilitasi pembentukan proses belajar dan pengetahuan melalui aksi dan interaksi yang berarti.

Media pembelajaran online menurut Vito (2011) dapat diartikan sebagai media yang dilengkapi dengan alat pengontrol yang dapat dioperasikan oleh pengguna (user), sehingga pengguna (user) dapat mengendalikan dan mengakses apa yang menjadi kebutuhan pengguna, misalnya mengunduh sumbersumber untuk materi, termasuk materi yang terdapat pada layanan bimbingan konseling.

Media pembelajaran offline menurut Rada (2001) dapat diartikan sebagai media yang tidak dilengkapi dengan alat pengontrol/ navigasi yang dapat digunakan oleh pengguna (user) media ini berjalan secara berurutan (in sequence). Misalnya media persentasi layanan bimbingan konseling yang pada umumnya tidak dilengkapi alat untuk mengontrol apa yang akan dilakukan oleh pengguna. Persentasi berjalan biasanya digunakan bila jumlah peserta didik 
lebih dari satu orang, sebagai contoh dapat dapat diwujudkan dalam bentuk CD.

Terkait hal ini, menurut Nasution (2008) ada beberapa media pembelajaran online yang bisa dijadikan pilihan pemberian layanan bimbingan konseling, di antaranya, yaitu: media online yang pertama dan paling banyak digunakan adalah whatsapp group, zoom, media online selanjutnya berasal dari google, yaitu google suite for education, media online ruang guru, media online zenius.

Media layanan bimbingan konseling lainnya juga bisa memanfaatkan google form untuk mengetahui hasil pemahaman peserta didik melalui penyebaran angket atau skala penilaian. Salah satu aplikasi pendukung lainnya yang juga sangat membantu proses berjalannya konseling adalah aplikasi cyber counseling (konseling berbasis dunia maya) adalah layanan konseling profesional yang melibatkan konselor dan konseli melalui media video conference, yang memungkinkan bertatap muka secara online dari layar monitor komputer/ smart phone tanpa menuntut kehadiran kedua belah pihak secara fisik serta dapat dilakukan kapan dan dimana saja. Media yang digunakan antara lain: website, blog, email, facebook, yahoo messanger, twitter, instagram teleconferencel videoconference (skype, videocall, google meet, zoom, hangout).

Berdasarkan hal di atas melihat situasi dan kondisi pada masa pandemi covid-19 konselor harus cerdas memilih media layanan bimbingan konseling yang harus digunakan dalam proses layanan supaya berhasil sesuai tujuan.

\section{METODE}

Metode penelitian menggunakan jenis penelitian studi kepustakaan. Studi kepustakaan memberikan penelusuran pustaka yang lebih dimana kegiatannya membatasi pada pengumpulan bahan-bahan koleksi perpustakaan (Zed, 2008). Langkah-langkah yang digunakan dala penelitian kepustakan meliputi (Khatibah, 2011):

1. Menyiapkan alat yang dibutuhkan dalam penelitian kepustakaan.

2. Menyusun bibliografi kerja atau sebuah catatan mengenai bahan sumber yang akan digunakan dalam penelitian kepustakaan.

3. Mengatur waktu dalam melakukan penelitian kepustakaan.

4. Membaca dan membuat sebuah catatancatatan penelitian.

\section{HASIL}

Media layanan bimbingan dan konseling dimasa pandemi covid-19 menyesuaikan peraturan mentri secara daring. Dimana tugas bimbingan konseling membantu mengatasi dampak yang ditimbulkan akibat dari pembelajaran daring di rumah. Pemberian layanan bimbingan konseling secara daring dapat melalui media online dan offline diantaranya whatsapp, google suite for education, cd, google form, website, blog, email, facebook, yahoo messanger, twitter, instagram teleconference/ videoconference skype, videocall, google meet, zoom, hangout, 
google classroom, rumah belajar, telepon atau live chat, cyber counseling.

Pemberian layanan bimbingan sosial bisa diimplementasikan melalui penggunaan media zoom atau google meet untuk peserta didik. Peserta didik diajak untuk saling mengutarakan apa yang dirasakan dan diharapkan dari pengalaman proses belajarnya maupun kesehariannya di masa pandemi covid-19. Guru bimbingan dan konseling bisa memberikan video atau gambaran karier dari seorang tokoh yang bisa diambil sisi positifnya.

Makna disini menekankan kepada konselor sebagai seorang profesional harus mampu mengikuti tuntutan zaman agar tetap bisa memberikan layanan atau tugasnya secara optimal. Zaman disini sudah mengarah kepada penggunaan teknologi sebagai media layanan bimbingan konseling yang sangat umum yakni penggunaan gadget atau aplikasi yang memudahkan orang untuk belajar dan berinteraksi.

\section{PEMBAHASAN}

Media-media tersebut dapat digunakan pada layanan bimbingan konseling yang menuntut penguasaan teknologi. Misalnya layanan bimbingan pribadi bisa diberikan melalui cyber counseling (konseling berbasis dunia maya) adalah layanan konseling profesional yang melibatkan konselor dan konseli melalui media videoconference, yang memungkinkan bertatap muka secara online dari layar monitor komputer/ smartphone tanpa menuntut kehadiran kedua belah pihak secara fisik serta dapat dilakukan kapan dan dimana saja. Media layanan Cyber counseling memiliki implikasi terhadap optimalisasi peran konselor dan profesionalisme dalam pemanfaatan cyber counseling untuk pengembangan informasi dan pengembangan sumber daya teknologi (Prasetya, dkk., 2020). Cyber counseling juga dapat memotivasi peserta didik untuk belajar dan tetap tinggal di rumah serta mengembangkan life skill di masa pandemi secara online. Hal ini sesuai dengan yang disampaikan Nurihsan (2005) bahwa layanan bimbingan pribadi yang bersifat membantu peserta didik dalam menemukan dan mengembangkan dirinya menjadi individu yang taat beragama, mandiri serta sehat secara fisik dam psikis. Selain itu guru bimbingan dan konseling juga bisa memberikan motivasi dalam bentuk video (CD) ataupun hal lainnya untuk menguatkan peserta didik ditengah pandemi covid-19.

\section{SIMPULAN}

Pandemi covid-19 yang terjadi di seluruh dunia menjadikan berubahnya proses pembelajaran termasuk di Indonesia. Maka konselor juga terkena dampaknya, yang akhirnya bimbingan konseling juga harus melakukan transformasi pada media layanan dalam menyikapi pandemi covid-19 ini.

Bimbingan konseling harus memastikan kegiatan layanan tetap berjalan, meskipun peserta didik berada di rumah. Solusinya, konselor dituntut mendesain media layanan bimbingan konseling sebagai inovasi dengan 
memanfaatkan media daring (online). Ini sesuai arahan Menteri Pendidikan dan Kebudayaan RI Nadiem Makarim merespon dengan belajar di rumah menggunakan media daring. Sistem teknologi layanan bimbingan konseling dilaksanakan melalui perangkat teknologi yang terhubung dengan koneksi jaringan internet.

Pemberian layanan bimbingan konseling secara daring dapat melalui media online dan offline diantaranya whatsapp, google suite for education, cd, google form, website, blog, email, facebook, yahoo messanger, twitter, instagram teleconferencel videoconference skype, videocall, google meet, zoom, hangout, google classroom, rumah belajar, telepon atau live chat, cyber counseling. Melalui media tersebut, konselor dapat memberi tugas terukur sesuai dengan tujuan materi layanan yang disampaikan kepada peserta didik dan juga dapat melakukan layanan bimbingan konseling bersama di waktu yang sama. Dengan demikian, konselor dapat memastikan peserta didik mengikuti layanan dalam waktu bersamaan, meskipun di tempat yang berbeda.

\section{DAFTAR RUJUKAN}

Aji, R.H.S. (2020). Dampak Covid-19 pada Pendidikan di Indonesia: Sekolah, Keterampilan, dan Proses Pembelajaran. Jurnal Sosial \& Budaya Syar-i, Vol.7 No.5.

Ahmad Arsyad, Media Pembelajaran. (Jakarta: Raja Grafindo Persada, 2005), 45.

Dabbagh, N. and Ritland. B. B, Online Learning, Concepts, Strategies And Application. Ohio: Pearson, 2005), 78. Baca juga Mayer, R. E, Multi Media
Learning Prinsip-Prinsip Dan Aplikasi. (Yogyakarta: Pustaka Pelajar, 2009), 67.

DeVito. Joseph A. (2011). Komunikasi Antarmanusia Edisi Kelima. Alih Bahasa Maulana. Agus. (Tangerang Selatan : Karisma, 2011), 67.

Hafidzah, D.(2020). Pentingnya BK di Masa Pandemi. Surabaya: Kompas. 15 Agustus Jurnal Bimbingan Konseling. 9 (2), 144-150.

Khatibah. (2011). Penelitian Kepustakaan. Jurnal Iqra'. 5 (1), 36-39.

Nurihsan, A. J. (2005). Strategi Layanan Bimbingan dan Konseling. Bandung: PT Refika Aditama.

Panduan Penyelenggaraan Pembelajaran pada Tahun Ajaran 2020/2021 dan Tahun Akademik 2020/2021 Bagi Satuan Pendidikan Madrasah, Pesantren, Pendidikan Keagamaan Islam, dan Perguruan Tinggi Keagamaan Islam di Masa Pandemi Coronavirus Disease 2019 (COVID-19). Nomor : B1673.1/DJ.I/08/2020.

Prasetya, D. A., dkk. (2020). Web-based Cyber Counseling to improve Students' Counseling Interest.

Rada, R, Understanding Virtual Universities. (USA: Intellect, 2001), 87.

Siaran PERS. Panduan Penyelenggaraan Pembelajaran Pada Tahun Ajaran dan Tahun Akademik Baru di Masa Pandemi Covid-19. Nomor

137/sipres/A6/VI/2020.

Winkel \& Widiahastuti, S. (2013). Bimbingan dan Konseling di Institusi Pendidikan. Yogyakarta:Media Abadi

Zed, M. (2008). Metode Penelitian Kepustakaan. Jakarta: Yayasan Obor Indonesia 